\title{
Inherent case in Archaic Chinese
}

\author{
Edith Aldridge*
}

\begin{abstract}
This paper proposes an analysis of subject case in Late Archaic Chinese (LAC). By examining the distribution of first person pronominal subjects, I conclude that there were two distinct morphological cases for subjects in LAC. One of these pronouns, 我 wó, valued structural nominative case, while the other one, 吾 wú, was marked with a different case. The occurrence of 吾 wú as the external argument of experiencer and modal predicates clearly suggests that this case was at least sometimes inherent case assigned to the external argument in [Spec, $v \mathrm{P}]$. 吾 $w u ́$ also functioned as the subject of relative clauses, embedded subjunctive clauses, and irrealis matrix clauses. Since the case valued in these clause types was not sensitive to predicate types, I propose that the source of the case valued by the subject in these environments was T. Working within Chomsky's (2008) C-T Inheritance framework, I propose that Inheritance did not take place in indicative clauses, so the subject moved to $[\mathrm{Spec}, \mathrm{CP}]$ to value nominative case. A first person pronoun with nominative case was spelled out as 我 wǒ. But Inheritance was forced if another constituent needed to occupy [Spec, $\mathrm{CP}]$. I propose that relative clauses and irrealis/subjunctive clauses are all derived through operator movement. Because the operator must occupy [Spec, CP], C-T Inheritance must also take place, forcing the subject to move to [Spec, TP] to value its case. The case valued in this position was also the non-nominative form exemplified by the first person pronoun 吾 wú.
\end{abstract}

Keywords. C-T Inheritance; inherent case; nominalization; irrealis mood; subjunctive

1. Introduction. This paper proposes that Late Archaic Chinese (LAC; $5^{\text {th }}$ to the $3^{\text {rd }}$ centuries $\mathrm{BCE}$ ) had both nominative and non-nominative subjects. This is a surprising discovery, given that modern Sinitic languages lack any morphological evidence of case distinctions. In this paper, I argue on the basis of the distribution of first person pronominal subjects that subjects in LAC valued a case other than nominative in a variety of contexts, including embedded nominalized clauses, experiencer constructions, as well as modal and other irrealis environments.

To begin, it is generally acknowledged that the LAC third person pronominal paradigm can be characterized to a certain extent in terms of case distinctions. Different pronominal forms were used to express subjects, objects, and possessors. Personal pronouns are found as objects and possessors. Since LAC was a null subject language, there is no overt personal pronoun for third person subjects. When focused, these subjects were expressed with demonstratives (Ma 1898, Zhou 1959, Wang 1980, Lü 1982, Hong 1991, Pulleyblank 1995).

(1)Demonstrative (subject)

之 $z h \bar{\imath}$ (object)

其 $q i$ (possessor)

Examples are shown in (2) for object $z h \bar{\imath}$, possessor qí, and demonstrative subject, respectively.

\footnotetext{
*Author: Edith Aldridge, University of Washington (aldr@uw.edu).
} 
(2) a. 學而時習之, 不亦說乎?

Xué ér shí [xí

study CONJ time practice

( $5^{\text {th }}$ C. BCE; Analects, Xue'er)

'To study and periodically practice something, is this not joyful?'

b. 其子焉往?

$\left(4^{\text {th }}\right.$ C. BCE; Mencius, Lílóu 1)

qí zǐ yān wăng?

3.GEN son where go

'Where would their sons go?'

c. 是所使夫百吏官人為也。

$\left(3^{\text {rd }}\right.$ C. BCE; Xúnzǐ 11)

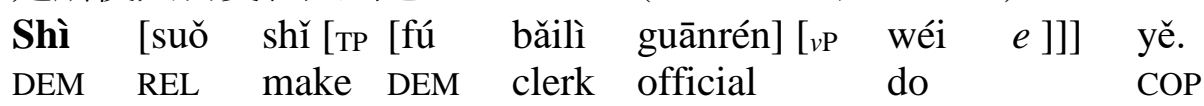

'This is something which one makes those clerks and officials do.'

Case morphology was not visible in the writing system on full noun phrases except for genitive, which was marked by 之 $z h \bar{l}$. This marker is homophonous with the $3^{\text {rd }}$ person object pronoun, and these share the same diachronic origin, attested first as a demonstrative pronoun. This pronoun grammaticalized into a neutral (non-deictic) determiner (Djamouri 1999) and, as the head of DP, could function as either a pronoun in argument position or a genitive case marker for a DP in its specifier (Aldridge 2009) ${ }^{1}$.

(3) 文王之直

[Wén wáng zhī yòu]

Wen king GEN park

'King Wen's park'

Case distinctions are less clear when it comes to first and second person pronouns. In the first person paradigm, three different forms are found in subject position, while two of these could also be used as objects or possessors (Ma, 1898, Wang 1980, Lü 1982, Pulleyblank 1995). The second person paradigm is similar, with two forms for subject and possessor, and only one form for objects.

(4) $1^{\text {st }}$ prs: 我 wǒ (subject, object, possessor)

$$
\begin{aligned}
& \text { 余 (予) yú ( (subject, object) } \\
& \text { 吾 } w u ́ \text { (subject, possessor) } \\
& 2^{\text {nd }} \text { prs:爾 } \mathrm{e} r \text {, 女 } r u \text { (subject, object, possessor) } \\
& \text { 而 ér } r \text { (subject, possessor) }
\end{aligned}
$$

Graham (1969) characterizes the system in terms of dependent (possessor and embedded subject), as opposed to independent (matrix subject and object), forms. The term "dependent" refers to the fact that these forms are contained within larger constituents, i.e. possessed nominals or embedded clauses. To a certain extent, the dichotomy between embedded and non-embedded forms is an accurate characterization. (5a) and (5b) show first person wǒ used as a matrix clause subject and object, respectively.

\footnotetext{
${ }^{1}$ See also Wang (1980), Zhou (1959), and Yue (1998) for additional discussion of the etymology and historical development of $z h \bar{l}$.
} 
(5) a. 我將死。

Wǒ jiāng sǐ.

( $5^{\text {th }}$ C. BCE; Zuǒzhuàn, Xiāng 25)

1.DFLT will die

'I am going to die.'

b. 請殺我乎!

Qǔng shā wǒ hū!

please kill 1. DFLT EXCL

'Please kill me!'

( $5^{\text {th }}$ C. BCE; Zuǒzhuàn, Huán 16)

In contrast to this, wú was much more commonly employed as a possessor, as in (6a), and also frequently functioned as the subject of an embedded clause, as in (6b).

(6) a. 吾父之旗也。

$\left(5^{\text {th }}\right.$ C. BCE; Zuǒzhuàn, Āi 13)

[Wú fù] zhī qí yě.

1.GEN father GEN flag COP

'(It) is my father's standard.'

b. 何由知吾可也?

Hé yóu zhī [wú kě ] yě?

what by know 1.GEN can ASP

'How do you know that I can?'

$\left(4^{\text {th }}\right.$ C. BCE; Mencius, Liáng Huí 1)

However, the "independent/dependent" dichotomy does not account for the full distribution of these pronouns. As (7a) shows, wǒ could function as a possessor, and wú is sometimes found in matrix subject position, as in (7b).

(7) a. 秋, 師及齊師戰于乾時, 我師敗績。 $\quad\left(5^{\text {th }} \mathrm{C}\right.$. BCE; Zuǒzhuàn, Zhuāng 9)

Qiū shī jí Qí shī zhàn yú Gānshí,

fall army with Qi army fight in Ganshi

wǒ shī bàijī.

1. DFLT army defeat

'In the fall, the army battled with the Qi army in Ganshi and our forces were defeated.'

b. 諾。吾將復請。

( $5^{\text {th }}$ C. BCE; Zuǒzhuàn, Xī 10)

Nuò wú jiāng fù qĭng.

yes 1.GEN will again ask

'OK, I will ask again.'

In this paper, I argue in favor of a different distinction between wǒ (WO) and $w u ́(\mathrm{WU})$. I maintain that WO and WU were clearly distinguished on the basis of case, at least in the early LAC period exemplified by the $5^{\text {th }}$ century historical text Zuŏzhuàn. While WO occurs in positions for structural nominative and accusative cases, WU was an inherently case-marked form. In this paper, I gloss it as "genitive", as it occurs as a possessor within noun phrases and as the subject of embedded clauses which are plausibly analyzed as nominalizations, as I discuss in section 2.1. The occurrence of WU in main clauses is rather limited. WU can easily be analyzed as valuing inherent case when it functions as the subject of psychological and certain modal predicates, as these are common environments for inherently case-marked subjects cross linguistically, as shown in section 2.2. In section 3, I show that WU is also found as the subject of matrix irrealis clauses. I propose a uniform analysis of subject case in both embedded nominalizations and root 
irrealis clauses in section 4. Put simply, I posit that subjects must value a case other than nominative in these clause types, because the position for nominative case is not available.

As mentioned above, WO also sometimes surfaces in positions where WU is expected. There are two conditions on the substitution of WO for WU. As WU could only be used with singular referents, WO was required when the referent was plural, as in (7a). WO was also used when this DP was stressed, as in a contrastive focus environment. Since WO is found in positions for nominative, accusative, as well as inherently case-marked DPs, I propose that it could value any case in the syntax and was spelled out post-syntactically as the default form of the first person pronoun. In contrast, WU surfaced only in positions where structural nominative and accusative were not available, so I analyze it as an inherently case-marked pronoun.

In this short work, I confine my examination to the two first person pronouns WO and WU. I do not consider the remaining first person pronoun $y u ́$, as its distribution was determined by sociolinguistic criteria, typically used by speakers addressing social inferiors, e.g. fathers to sons or teachers to students. I also do not examine second person pronouns in this paper, though my current understanding of their distribution leads me to believe that they exhibit the same basic pattern as their first person counterparts. Finally, it must be acknowledged that third person pronouns do not fully mirror the distribution of first person pronouns. Though first and third person pronouns behave identically when functioning as possessors and embedded subjects, as I show in section 2.1, non-nominative third person subjects are not found in matrix clauses. I assume that this is due to the pro-drop nature of LAC: third person pronominal subjects take overt form only when stressed, and when they are stressed, they are expressed as demonstratives, as mentioned above.

2. WU as a pronoun with inherent case. In this section, I present examples of WU occurring in environments where inherently case-marked nominals commonly occur cross linguistically. This discussion provides the foundation for my proposal that WU was an inherently case-marked form.

2.1. POSSESSOR AND SUBJECT OF A NOMINALIZED CLAUSE. As mentioned in the previous section, WU commonly occurs as a possessor.

(8) a. 吾父之旗也。

( $5^{\text {th }} \mathrm{C} . \mathrm{BCE} ;$ Zuǒzhuàn, Āi 13$)$

[DP Wú fù] zhī qí yě.

1.GEN father GEN flag COP

'(It) is my father's standard.'

b. 或以吾城叛。 $\quad\left(5^{\text {th }}\right.$ C. BCE; Zuǒzhuàn, Zhāo 15)

Huò yř [DP wú chéng] pàn.

someone APPL 1.GEN city surrender

'Someone surrenders my city.'

As pointed out in the previous section, WO could also function as a possessor, but only when the referent was plural in number. I assume this to be a retention from Pre-Archaic Chinese $\left(14^{\text {th }}-\right.$ $11^{\text {th }}$ century BCE), where WO was principally employed as a plural form (Zhou 1959, Yang \& He 1992, Zhang 2001), while another pronoun expressed first person singular. WU is not found in Pre-Archaic Chinese, first attested in Early Archaic Chinese $\left(10^{\text {th }}-6^{\text {th }}\right.$ centuries BCE $)$. Though WO later came to refer to both singular and plural referents, WU was always singular, so I assume that WO had to be used when the referent was plural. 
（9）a. 秋，師及齊師戰于乾時，我師敗績。 $\left(5^{\text {th }}\right.$ C. BCE; Zuǒzhuàn, Zhuāng 9)

$\begin{array}{llllll}\text { Qiū } & \text { shī } & \text { jí } & \text { Qí shī } & \text { zhàn } & \text { yú Gānshí, } \\ \text { fall } & \text { army } & \text { with } & \text { Qi army } & \text { fight } & \text { in Ganshi } \\ \text { wǒ } & \text { shī } & \text { bàijīi }\end{array}$

1. DFLT army defeat

'In the fall, the army battled with the Qi army in Ganshi and our forces were defeated.'

b. 丁未, 葬我君成公。

Dīngwèi, zàng wǒ jūn Chéng Gōng.

Dingwei bury 1. DFLT lord Cheng Duke

'On the day dingwei, (we) buried our lord Duke Cheng.'

WU also functioned as the subject of a nominalized embedded clause, such as a relative clause formed on object position. (10) shows an example with a full NP embedded subject, which is clearly marked genitive. The relativization marker suó appears between the subject and VP in the embedded clause.

$$
\begin{aligned}
& \text { 其北陵, 文王之所避風雨也。 }\left(5^{\text {th }} \mathrm{C}\right. \text {. BCE; Zuǒzhuàn, Xī 32) } \\
& \text { Q1́ běi líng [Wén Wáng zhī suǒ [vpbì fēng yŭ_ ]] yě. } \\
& \text { 3.GEN north hill Wen king GEN REL escape wind rain COP } \\
& \text { 'The north hill is [where the (Zhou) king Wen took shelter from the storm].' }
\end{aligned}
$$

(11) shows examples with first person subjects. The pronoun is WU and not WO.
a. 吾所問日食, 從矣。
( ${ }^{\text {th }}$ C. BCE; Zuǒzhuàn, Zhāo 7)
[Wú suǒ wèn rìshí], cóng y̌̃.
1.GEN REL ask eclipse happen ASP
'The eclipse I asked about has already taken place.'
b. 或以吾城叛, 吾所甚惡也。

$\begin{array}{cllll}\text { Huò } & \text { yí } & \text { wú chéng pàn, } \\ \text { someone } & \text { APPL } & 1 . \text { GEN city } & \text { surrender } \\ \text { [wú } & \text { suǒ } & \text { shèn wù ] yě. } & \text { yé } \\ \text { 1.GEN } & \text { REL } & \text { greatly hate } & \text { COP }\end{array}$
( $5^{\text {th }}$ C. BCE; Zuǒzhuàn, Zhāo 15)
'Someone surrendering my city, (that) is something I detest.'

Temporal adverbial clauses were also nominalized in LAC. (12a) shows an example with a third person subject followed by the genitive case marker. (12b) shows an example with a first person subject, and this subject is WU.
a. 晉侯之入也, 秦穆姬屬賈君焉。
$\left(5^{\text {th }} \mathrm{C}\right.$. BCE; Zuǒzhuàn, X̄̄ 15)
[Jìn hóu zhī rù yě], Qín Mù Jī shǔ Jiă Jūn yān.
Jin marquis GEN return ASP Qin Mu Ji give Jia Jun 3.DAT
'When the Marquis of Jin returned, Mu Ji of Qin gave Jia Jun to him.'
b. 昔吾畜於趙氏, 孟姬之堍, 吾能違兵。 $\quad\left(5^{\text {th }} \mathrm{C}\right.$. BCE; Zuŏzhuàn, Chéng 17)

$\begin{array}{lllllllll}{[\text { Xí }} & \text { wú } & \text { xù } & \text { yú } & \text { Zhào } & \text { shì, } & \text { Mèng Jī } & \text { zhī } & \text { chán] } \\ \text { past } & 1 . \text { GEN } & \text { support } & \text { by } & \text { Zhao } & \text { clan } & \text { Meng Ji } & \text { GEN } & \text { slander }\end{array}$


wú néng wéi bīng.

1 can avoid soldier

'In the past, when I was being supported by the Zhao clan and suffered Meng Ji's slander, I was able to avoid the soldiers (and escape).'

Complements of factive verbs and psychological predicates were nominalized as well. (13) shows examples with third person embedded subjects.
a. 未知母之存否。
( $5^{\text {th }} \mathrm{C}$. BCE; Zuǒzhuàn, Xuān 2)
Wèi zhī [CP mŭ
not.yet know mother
$\begin{array}{lll}\text { zhī } & \text { cún } & \text { fǒu]]. } \\ \text { GEN } & \text { be.alive } & \text { not.be }\end{array}$

'(I) do not yet know whether my mother is alive or not.'
b. 懼君威之不立。
Jù [CP jūn wēi zhī bù lì ].
fear lord image GEN not establish].

'(I) fear that my lord's reputation will not be firmly established.'

(14) shows corresponding first person examples with WU as the subject.
a. 今吾聞至人之言,
Jīn wú wén zhì rén zhī yán,
now 1 hear great man GEN word
恐吾無其實，輕用吾身而亡其國。（ ${ }^{\text {th }} \mathrm{C}$. BCE; Zhuāngž̌, Déchōngfú $)$
kǒng [wú wú qí shí, qīng yòng wú shēn
fear 1.GEN lack 3.GEN substance light use 1 body
ér wáng qí guó].
CONJ lose 3.GEN nation

'Now that I have heard the words of a great man, I fear that I will lack his ability, will employ myself lightly, lose the nation.'

b. 何由知吾可也?

$\left(4^{\text {th }}\right.$ C. BCE; Mencius, Liáng Huí 1)

Hé yóu zhī [wú kě ] yě?

what by know 1.GEN can ASP

'How do you know that I can?'

This subsection has presented examples in which WU clearly occupies the position for a genitive nominal: possessor within a noun phrase and subject of a nominalized clause. For the analysis, I assume that genitive case was assigned to possessors in the specifier of DP and also to the subject occupying the specifier of the embedded TP. I explore the analysis of embedded subject case further in section 4 and offer an explanation as to why these embedded clauses were nominalized - or more to the point, why they had to have genitive subjects. In the next subsection, I show examples of WU functioning as the subject of certain types of matrix clause that can also reasonably be expected to have non-nominative subjects.

2.2. WU AS THE SUBJECT OF PSYCHOLOGICAL AND MODAL PREDICATES. WU is also found as the subject of certain types of matrix clauses, for example those employing psychological or perception predicates. 
a. 吾見師之出而不見其入也。 $\quad\left(5^{\text {th }}\right.$ C. BCE; Zuǒzhuàn, Xī 32)

Wú jiàn shī zhī chū ér bù jiàn qí rù yě.

1.GEN see army GEN exit CONJ NEG see 3.GEN enter NMLZ 'I see the army's departure but will not see them return.'

b. 吾恐其為天下笑。

$\left(4^{\text {th }}\right.$ C. BCE; Zhuāngž̀, Xúwúguǐ $)$

Wú kŏng [qí wéi tiānxià xiào].

1.GEN fear 3.GEN PASS world laugh

'I fear that he will be laughed at by the whole world.'

This is not surprising, given that it is common across languages for subjects of psych predicates to appear with non-nominative case, as in the Icelandic examples in (16).

Icelandic (Baker 2013:17-18)
a. Henni leiddust peir.
her.DAT was.bored.by.3PL they.NOM
'She was bored with them.'

$\begin{array}{lll}\text { b. Henni leiðist } & \text { bókin } & \text { sín. } \\ \text { her. DAT } & \text { was.bored.by.3sG book } & \text { self’s }\end{array}$

'She was bored with her own book.'

I assume with Woolford (2006) that experiencer subjects of psychological and perception predicates receive inherent case in their base positions [Spec, $v \mathrm{P}]$ and later move to surface subject position to check the EPP.

WU is also found as the subject of ability modals such as néng 'can'.

a. 吾能改矣。

( $5^{\text {th }}$ C. BCE; Zuǒzhuàn, Xuān 9)

Wú néng găĭ y̌̃.

1.GEN can change ASP

'I can change.'

b. 昔吾畜於趙氏, 孟姬之堍, 吾能違兵。 $\quad\left(5^{\text {th }} \mathrm{C}\right.$. BCE; Zuǒzhuàn, Chéng 17)

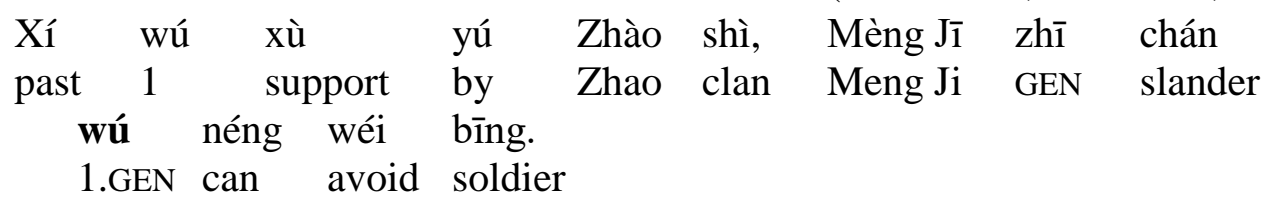

'In the past, when I was being supported by the Zhao clan and suffered Meng Ji's slander, I was able to avoid the soldiers (and escape).'

Again, this is not surprising from a crosslinguistic perspective. Some languages, for example Japanese, also employ non-nominative subjects in such contexts.

Japanese
a. Taroo $=$ ga Chuugokugo $=0$ hanasite-ire.
Taro=NOM Chinese $=$ ACC $\quad$ speak-be
'Taro is speaking Chinese.'
b. Taroo $=$ ni Chuugokugo $=$ ga hasas-e-ru.
Taro $=$ DAT $\quad$ Chinese $=$ NOM $\quad$ speak-POT-PRES
'Taro can speak Chinese.'


Koizumi (1995), Bobaljik and Wurmbrand (2007), Takahashi (2012) have proposed that subjects of the Japanese ability modal are selected by the verbal head hosting the modal, which in current Minimalism is $v$. I further assume that this $v$ is responsible for assigning inherent case to the subject. Consequently, the same analysis can be adopted for subjects of modal predicates as for subjects of psychological predicates: they receive inherent case in [Spec, $v \mathrm{P}]$.

Incidentally, WO is also sometimes found as the subject of an ability modal, subject to the conditions I summarized in section 1 . Since WU could only be singular, WO was required when the subject was plural, as in (19a). WO was also used in contrastive focus contexts such as (19b).
a. 涉佗、成何曰:「我能盟之。」 Shè Tuó, Chéng Hé Yuē: "Wǒ néng méng zhî."
She Tuo Cheng He say 1.DFLT can ally 3.ACC
'She Tuo and Cheng He said: "We can form the alliance with them.",
b. 我能死, 爾能報。
$\left(5^{\text {th }}\right.$ C. BCE; Zuǒzhuàn, Zhāo 20)

This section has shown a variety of syntactic environments in which WU can plausibly be analyzed as an inherently case-marked form. In the next section, I turn to some examples which are less obvious from a cross linguistic standpoint. All of them show WU as the subject of a matrix clause in irrealis mood. However, I argue in section 4 that these, too, should be analyzed as nonnominative subjects.

3. Realis versus irrealis. In this section, I show that WU is found as the subject of irrealis clauses. First, WU occurs with the modal qí, which He (2004) classifies as expressing future probability, necessity, or volition.
a. 吾其廢乎?
Wú qí
fèi
(5 ${ }^{\text {th }}$ C. BCE; Zuozhuan, Mǐn 2)
1.GEN MOD disinherit $Q$
'Am I to be disinherited?'
b. 孰殺子產, 吾其與之。
( $5^{\text {th }}$ C. BCE; Zuǒzhuàn, Xiāng 30)
Shú shā Zĩ Chăn, wú qí yǔ zhī.
who kill Zi Chan 1.GEN MOD help 3.GEN
'Whoever kills Zichan, I will help him.'

WO is generally not found with the modal qí. However, before concluding that WU is assigned inherent case by the $v$ hosting this modal, I consider some environments in which both WU and singular, unstressed WO can occur and show that the difference in the subject form correlates with a difference in mood: WU is the subject of irrealis clauses, while WO is the subject of realis clauses. In the following two examples, WO and WU occur, respectively, as the subject preceding the future marker jiäng. In (21a), where WO is the subject, the event being expressed took place prior to utterance time and consequently had already been realized by that time. (21b), with WU as the subject, expresses a future event, posterior to utterance time and consequently has not been realized. The example with WU as the subject, then, can be said to be an example of irrealis mood. 
a. 我將亡, 夫子存我, 德莫大焉。 $\left(5^{\text {th }}\right.$ C. BCE; Zuǒzhuàn, Xiāng 27)

Wǒ jiāng wáng, fūž̌ cún wǒ, dé mò dà yān. 1.DFLT will die master save 1 virtur none large 3.DAT

'When I was about to die, the master saved me; there is no greater virtue than that.'

b. 諾。吾將復請。

$\left(5^{\text {th }} \mathrm{C}\right.$. BCE; Zuǒzhuàn, Xī 10)

Nuò wú jiāng fù qùng.

yes 1.GEN will again ask

'OK, I will ask again.'

WU is also frequently found in the consequent clause in a conditional sentence. Since these sentences express hypothetical situations, they are also examples of irrealis mood.

a. 苟舍我, 吾請納君。 $\quad\left(5^{\text {th }} \mathrm{C}\right.$. BCE; Zuǒzhuàn, Zhuāng 14)

Gǒu shè wǒ, wú qǐng nà jūn.

if release 1.DFLT 1.GEN ask restore lord

'If you release me, I will ask to have you, my lord, restored.'

b. 荷能納我, 吾使爾為卿。 $\quad\left(5^{\text {th }} \mathrm{C}\right.$. BCE; Zuŏzhuàn, Xī 30)

Gŏu néng nà wǒ, wú shǐ ěr wéi qīng.

if can restore 1.DFLT 1.GEN make 2.DFLT be minister

'If you can restore me, I will make you a minister.'

WO can be found as the subject of the same verbs but in realis mood. Both of the following examples express present or past events. The second clause in (23b) makes it particularly clear that the event expressed by the first clause has been realized.

a.「我請誘之。」子庚從之。 $\left(5^{\text {th }}\right.$ C. BCE; Zuŏzhuàn, Xiāng 13)

"Wǒ qǐng yòu zhī." Zĭgēng cóng zhī.

1.DFLT ask entice 3.OBJ Zigeng follow 3.OBJ

"I request that we entice them (leading them into a trap)." Zigeng followed this (suggestion).'

b. 今我使二國暴骨, 暴矣。 $\quad\left(5^{\text {th }}\right.$ C. BCE; Zuǒzhuàn, Xuān 12)

Jīn wǒ shǐ èr guó pù gǔ, pù yì.

now 1.DFLT make 2 nation bleach bone bleach ASP

'Now, I have made both nations bleach their bones (on the field of battle), and indeed (their bones) have been bleached.'

A further indication that WU appears as the subject of irrealis clauses is that it frequently occurs in $w h$-questions and negated clauses, typical irrealis environments.

a. 且人有君而斌之, 吾焉得死之? $\quad\left(5^{\text {th }} \mathrm{C}\right.$. BCE; Zuǒzhuàn, Xiāng 25)
Qiè rén you jūn ér shì $\quad$ zh̄i,
ADV person have lord CONJ assassinate 3.ACC
wú yān dé sǐ zhĩ?
1.GEN how can die 3.ACC
'If a man has a lord and assassinates him, how can I die for him?'


b. 吾弗敬子矣。

$\begin{array}{llll}\text { Wú fú } & \text { jìng } & \text { zĩ } & \text { yǐ. } \\ \text { 1.GEN NEG } & \text { respect } & \text { sir } & \text { ASP } \\ \text { 'I no longer respect you, sir.' } & \end{array}$

(5 $5^{\text {th }}$ C. BCE; Zuǒzhuàn, Zhuāng 11)

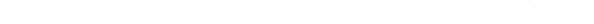

In this section, I showed that WU functions as the subject of irrealis clauses, regardless of the specific predicate. Consequently, it cannot be analyzed as receiving inherent case in the specifier of the $\nu \mathrm{P}$ projected by the predicate. In the next section, I propose an analysis of subjects in irrealis clauses that is parallel to that for subjects in nominalized clauses. Specifically, I propose that both clause types are operator movement contexts, and operator movement prevents the subject from moving to the nominative case position, because this position also functions as the landing site for the operator. Consequently, subjects in these clause types must occupy a lower position and receive non-nominative case.

4. Analysis. To summarize the discussion so far, the first person pronoun WU is found as a possessor, the subject of a psychological predicate, the subject of an ability modal, the subject of an embedded nominalized clause, and the subject of a matrix irrealis clause. As mentioned in section 2, I assume that possessors receive genitive case in the specifier of DP, and the subjects of psychological predicates and ability modals receive inherent case in the specifier of $v$ hosting these predicates. It is also not surprising that the subjects of nominalized clauses receive nonnominative (particularly genitive) case. But there is a larger question which I have not yet addressed, and that is the reason why certain types of embedded clauses in LAC had to be nominalized in the first place. In this section, I address this question by proposing an analysis of subject case in nominalized clauses which also accounts for the appearance of non-nominative subjects in irrealis clauses. Specifically, I propose that subjects in both clause types are prevented from moving to the position where nominative case is valued, because this position was required by an operator.

This analysis is grounded in Chomsky's (2008) C-T Inheritance model, which proposes that the features responsible for licensing nominative arguments are not inherent to $\mathrm{T}$ but rather enter the derivation on C and are then "inherited" by T from C. In particular, C passes $[u \phi]$ to T, which undergoes Agree with the subject, valuing nominative case and copying the subject's $\phi$-features to be spelled out as agreement. The subject is also attracted to the specifier of TP. If $\mathrm{C}$ has a feature driving A'-movement like a $[u \mathrm{WH}]$ feature, this feature is retained by $\mathrm{C}$, allowing movement to [Spec, $\mathrm{CP}]$ over the subject in [Spec, TP], as in case of object $w h$-movement.
a. What did you buy?
b. [СР what did [тр you [vР $\mathrm{t}_{\text {what }}\left[v^{\prime} \mathrm{t}_{\text {you }}\left[v^{\prime} v\left[\right.\right.\right.$ buy $\left.\left.\left.\left.\left.\left.\mathrm{t}_{\text {what }}\right]\right]\right]\right]\right]\right]$

Chomsky (2008) assumes that C-T inheritance takes place universally, but there is a growing body of literature arguing that this cannot be true for all clause types in all languages (Ouali 2006; Gallego 2014; Legate 2014; Martinović 2015; van Urk 2015; Erlewine 2016; Aldridge 2017). In Aldridge (2017), I argue specifically that C-T Inheritance did not generally take place in LAC and that subjects moved to [Spec, $\mathrm{CP}]$ rather than [Spec, TP] in order to value nominative case.

$$
\begin{aligned}
& \text { a. 鄭伯亦惡之。 } \\
& \text { Zheng bo yi } \quad \text { wu zhi. } \\
& \text { Zheng earl also dislike 3.oBJ } \\
& \text { 'And the Earl of Zheng also disliked him.' }
\end{aligned}
$$




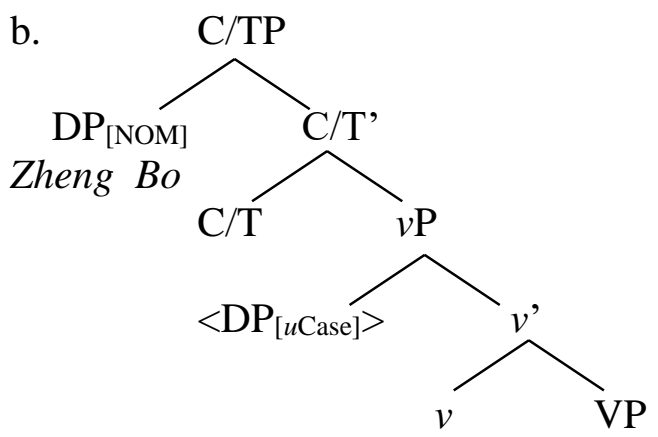

Evidence for this proposal comes from object movement contexts. Unlike English wh-movement, objects in LAC could never be dislocated over a nominative subject. Object topicalization provides evidence for this. Interestingly, this is another environment where WU is found as the subject of a root clause. In (27a), a topicalized object appears in clause-initial position, which I assume is [Spec, $\mathrm{CP}$ ]. The first person singular subject takes the form of WU and not WO. This is expected on my (2017) analysis, since the nominative case position [Spec, CP] is occupied by the object, so the subject is forced to surface in a lower position and value non-nominative case.

a. 諸侯之禮, 吾未之學也。 [Zhūhóu zhī lī] wú wèi zhī xué yě. feudal.lord GEN rite I.GEN not.yet 3.ACC study ASP 'The rites of the feudal lords, I have not yet studied.'

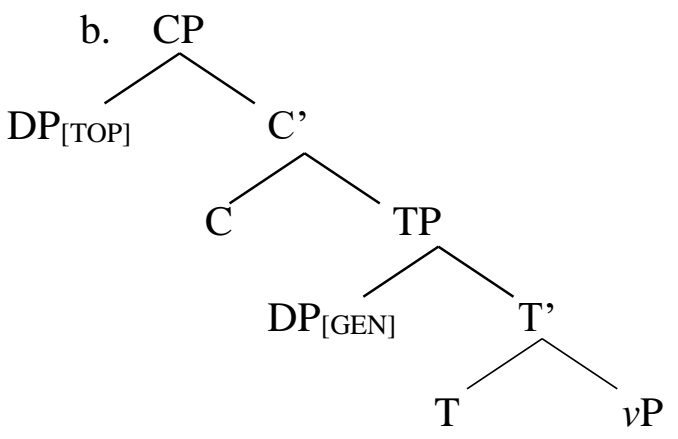

At this point, it is necessary to clarify my assumptions about the specific nature of the case valued by the subject in examples like (27a). There is no reason a priori to assume that genitive case is assigned to the subject located in [Spec, TP] in a finite indicative root clause. I propose rather than the case valued by the subject in examples like (27a) is in fact nominative, but nominative case has different morphological reflexes, depending on where it is valued. In other words, movement of the object to [Spec, CP] forced C-T Inheritance to take place in LAC, with the result that the case feature for the subject was also passed to $\mathrm{T}$. When nominative case was valued by $\mathrm{T}$, it was realized as the case that I gloss as "genitive". Interestingly, it is not uncommon cross linguistically for subjects appearing in different positions to be marked with different morphological cases. König (2008) shows that many African languages allow subjects to surface in either pre- or post-verbal position, but when the subject is post-verbal, it must be overtly marked for case, while it is unmarked when it surfaces in pre-verbal position. This, too, can be accounted for on my analysis by assuming that nominative has a different morphological reflex when it is valued in different positions. 
Chai (König 2008:248)
a. bume hayae yakogine.
Bume chase.PRV.3PL.3SG.OBJ Ngakogine.ACC
'The Bume chased Ngakogine.'
b. yakogine hayae
Ngakogine.ACC chase.PRV.3PL.3SG.OBJ Bume-NOM
'The Bume chased Ngakogine.'

The Aldridge (2017) analysis also accounts for the embedded clause types discussed in section 2.1. Recall first that object relative clauses in LAC had genitive subjects. I (2017) proposed that the subject could not be nominative, because nominative subjects had to occupy [Spec, CP]. But in a relative clause, this position is needed as the landing site for the operator moving to form the relative clause. In object relative clauses, then, C-T Inheritance is forced, in order to provide a position, i.e. [Spec, TP], for the subject. And as proposed above, the case valued by the subject in this position is spelled out as genitive.

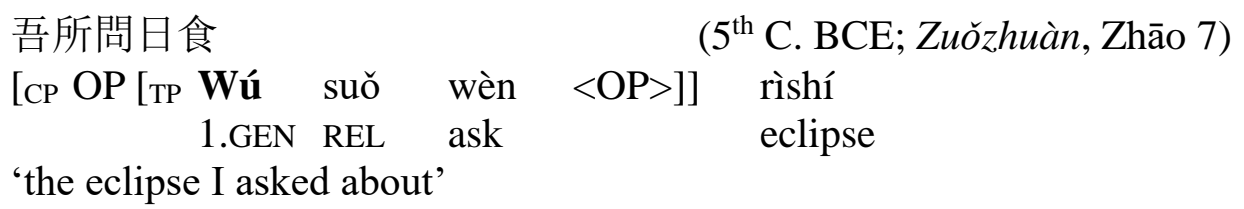

Turning to adjunct clauses like temporal adverbials, Larson (1987), Dubinsky \& Williams (1995), Demirdache \& Uribe-Etxebarria (2004), Haegeman (2007, 2010a) have argued that temporal adverbial clauses also involve operator movement to [Spec, $\mathrm{CP}]$ in the embedded clause. According to Haegeman (2010a), this accounts for the inability of other constituents, like topics, to undergo fronting in this type of embedded clause, because the landing site is occupied by the operator.

(30) a. John left [CP when [Sheila left the office]].

b. * John left [CР when [the office] [тр Sheila left <the office>]].

So it is not surprising that temporal adverbial clauses have genitive subjects in LAC. In order to allow the operator to move to [Spec, $\mathrm{CP}]$, the subject must be in $[\mathrm{Spec}, \mathrm{TP}]$.

$$
\begin{aligned}
& \text { 昔吾畜於趙氏, 孟姬之䜛, 吾能違兵。（ } 5^{\text {th }} \mathrm{C} \text {. BCE; Zuǒzhuàn, Chéng 17) } \\
& \text { [ср OP [тр Xí wú xù yú Zhào shì, Mèng Jī zhī chán]] } \\
& \text { past 1.GEN support by Zhao clan Meng Ji GEN slander } \\
& \text { wú néng wéi bīng. } \\
& 1 \text { can avoid soldier }
\end{aligned}
$$

'In the past, when I was being supported by the Zhao clan and suffered Meng Ji's slander, I was able to avoid the soldiers (and escape).'

Finally, this analysis accounts for why complements of certain matrix predicates, including psychological predicates and factive verbs, must be nominalized. Cross linguistically, these are all non-assertive, subjunctive contexts. ${ }^{2}$ Kempchinsky $(1986,2009)$ proposes that subjunctive complements of desiderative and directive verbs are characterized as having an imperative operator in the left periphery of the embedded clause. Haegeman and Ürögdi (2010) propose an operator

\footnotetext{
${ }^{2}$ See Quer (2009) for a general discussion of subjunctives in Romance languages.
} 
analysis of factive clauses in order to represent the definiteness of the presupposition expressed by these clauses. Bhatt and Pancheva (2006) and Haegeman (2010b) propose an operator movement analysis of another type of subjunctive environment: conditional clauses. They take the operator to range over a set of world variables. According to Haegeman, it is launched from the specifier of an irrealis mood phrase.

I build on these proposals by suggesting that operator movement takes place generally in non-assertive clauses in LAC. Following Bhatt and Pancheva (2006) and Haegeman (2010b), I propose that the operator ranges over a set of worlds in which the subjunctive proposition might be true. Operator movement to $[\mathrm{Spec}, \mathrm{CP}]$ in turn explains why non-assertive embedded clauses have genitive subjects in LAC. ${ }^{3}$ The subject had to occupy [Spec, TP] in order to make [Spec, $\mathrm{CP}$ ] available for the operator.
a. 懼君威之不立。
Jù [СР OP [тр jūn wēi zhī bù lì ]].
fear lord image GEN not establish].
'(I) fear that my lord's reputation will not be firmly established.'
b. 何由知吾可也?
Hé yóu zhī [сР OP [тр wú kě ]] yě?
what by know 1.GEN can ASP
( $4^{\text {th }}$ C. BCE; Mencius, Liáng Huí 1)
'How do you know that I can?'

I note in passing that assertive/indicative embedded clauses in LAC had nominative subjects. Note the lack of genitive marking on the embedded subjects in (33). This is expected, since assertive clauses do not involve movement of a world operator.

臣聞臬落氏將戰。
Chen wen [Gaoluo shi jiang zhan].
I hear Gaoluo tribe will fight
'I hear that the Gaoluo tribe is going to fight.'

At this point, there is an answer to the question of why subjects in certain embedded clause types were genitive rather than nominative: this was the consequence of C-T Inheritance in order to make $[\mathrm{Spec}, \mathrm{CP}]$ available for the operator in non-assertive clause types.

Turning to matrix irrealis clauses, I propose the same analysis as for their embedded counterparts. Irrealis clauses are also non-assertive clause types. Accordingly, it is reasonable to assume that their derivation also involves movement of a world operator movement to [Spec, $\mathrm{CP}]$. The subject then receives its case in [Spec, TP], which is spelled out as genitive.

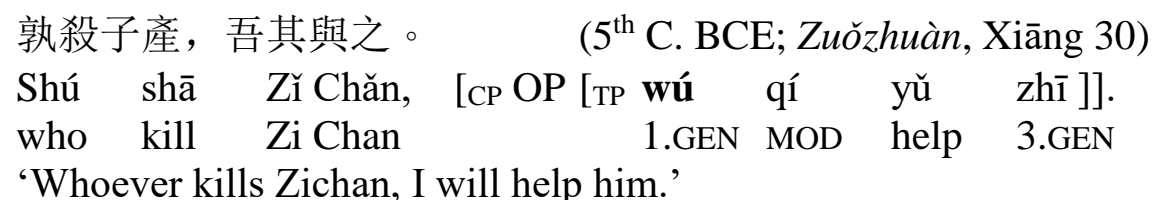

\footnotetext{
${ }^{3}$ The reader may wonder about conditional clauses in LAC. I leave out examples in order to save space, but these do indeed follow the anticipated pattern. Realis conditional clauses were full finite CPs employing a complementizer and had nominative subjects. In contrast, irrealis conditionals contained no complementizer and had genitive subjects. This dichotomy clearly shows the correlation between mood and subject case licensing.
} 
5. Conclusion. In this paper, I proposed that Late Archaic Chinese had two morphological cases for subjects, and these cases were valued in different structural positions. The language did not employ C-T Inheritance in indicative clauses, and nominative case was valued in [Spec, CP]. The language also had inherent case-marking for subjects of certain stative predicates like psychological verbs and ability modals. This case was assigned to external arguments in [Spec, $v \mathrm{P}]$. This "inherent" case form also appeared on nominative subjects if another constituent needed to occupy [Spec, CP]. The need for a second position in the left periphery forced C-T Inheritance to take place, and the subject then moved to [Spec, TP], where the case it valued was spelled out as the non-nominative form. In short, this paper proposed that the two subject cases in LAC are distinguished on the basis of whether the subject receives its case in [Spec, CP] (default nominative case) or another, structurally lower, position (non-default/genitive case).

\section{References}

Aldridge, Edith. 2009. Old Chinese determiner zhe. In Paola Crisma \& Giuseppe Longobardi (eds.), Historical syntax and linguistic theory. 233-248. Oxford: Oxford University Press.

Aldridge, Edith. 2017. Extraction asymmetries in ergative and accusative languages. In Michael Yoshitaka Erlewine (ed.), Proceedings of GLOW in Asia XI. 1-20. Cambridge, MA: MIT Working Papers in Linguistics.

Baker, Mark. 2013. On agreement and its relationship to case: Some generative ideas and results. Lingua 130. 14-32. https://doi.org/10.1016/j.lingua.2012.03.010.

Bhatt, Rajesh \& Roumyana Pancheva. 2006. Conditionals. In Martin Everaert \& Henk van Riemsdijk (eds.), The Blackwell companion to syntax. 638-687. Oxford: Blackwell.

Bobaljik, Jonathan \& Susi Wurmbrand. 2007. Complex predicates, aspect, and anti-reconstruction. Journal of East Asian Linguistics 16(1). 27-42. 10.1007/s10831-006-9004-y.

Chomsky, Noam. 2008. On phases. In Robert Freidin \& Carlos P. Otero (eds.), Foundational issues in linguistic theory: Essays in honor of J-R. Vergnaud. Cambridge, MA: MIT Press.

Djamouri, Redouane. 1999. The evolution of ZHI 之 in Archaic Chinese. In Alain Peyraube \& Sun Chaofen (eds.), Linguistic essays in honor of Mei Tsu-lin: Studies on Chinese historical syntax and morphology. 33-47. Paris: Centre de Recherches Linguistiques sur l'Asie Orientale.

Demirdache, Hamida \& Myriam Uribe-Etxebarria. 2004. The syntax of time adverbs. In Jacqueline Guéron \& Jacqueline Lecarme (eds), The syntax of time. 143-180. Cambridge, MA: MIT press.

Dubinsky, Stanley \& Kemp Williams. 1995. Recategorization of prepositions as complementizers: The case of temporal prepositions in English. Linguistic Inquiry 26. 125-137.

Erlewine, Michael Yoshitaka. 2016. Multiple extraction and voice in Toba Batak. In Hiroki Nomoto, Takuya Miyauchi \& Asako Shiohara (eds.), The Proceedings of the 23th Meeting of the Austronesian Formal Linguistics Association. 81-95. Canberra: Asia-Pacific Linguistics.

Gallego, Angel J. 2014. Deriving featuring inheritance from the copy theory of movement. The Linguistic Review 31(1). 41-71. 10.1515/tlr-2013-0021.

Graham, A. C. 1969. The Archaic Chinese pronouns. Asia Major 15(1). 17-61.

Haegeman, Liliane. 2007. Operator movement and topicalization in adverbial clauses. Folia Linguistica 18. 485-502.

Haegeman, Liliane. 2010a. The internal syntax of adverbial clauses. Lingua 120. 628-648. https://doi.org/10.1016/j.lingua.2008.07.007 
Haegeman, Liliane. 2010b. The movement derivation of conditional clauses. Linguistic Inquiry 41(4). 595-621.

Haegeman, Liliane \& Barbara Ürögdi. 2010. Referential CPs and DPs: An operator movement account. Theoretical Linguistics 36(2/3). 111-152. https://doi-org.offcampus.lib.washington.edu/10.1515/thli.2010.008.

Hong, Bo. 1991. Jianzhi daici de yuanshi jufa gongneng yanjiu [The original grammatical functions of demonstratives]. Guhanyu Yanjiu 1991(1). 35-43.

Kempchinsky, Paula. 1986. Romance subjunctive clauses and Logical Form. Los Angeles: University of California, Los Angeles, dissertation.

Kempchinsky, Paula. 2009. What can the subjunctive disjoint reference effect tell us about the subjunctive? Lingua 119(12). 1788-1810. https://doi.org/10.1016/j.lingua.2008.11.009.

Koizumi, Masatoshi. 1995. Phrase structure in Minimalist syntax. Cambridge, MA.: MIT dissertation.

König, Christa. 2008. Case in Africa. Oxford: Oxford University Press.

Larson, Richard. 1987. Missing prepositions and the Analysis of English free relative clauses. Linguistic Inquiry 18. 239-266.

Legate, Julie. 2014. Voice and v: Lessons from Acehnese. Cambridge, MA: MIT Press.

Lü, Shuxiang. 1982. Zhongguo wenfa yaolüe [Outline of Chinese grammar]. Beijing: Shangwu Yinshuguan.

Ma, Jian-zhong. 1898. Ma Shi wentong [Ma's Guide to the written language]. Shanghai: Shangwu Yinshuguan. Reprinted as: Ma Shi wentong duben, ed. by Shuxiang Lü and Haifen Wang. Shanghai: Shanghai Jiaoyu Chubanshe.

Martinović, Martina. 2015. Feature geometry and head-splitting: Evidence from the morphosyntax of the Wolof clausal periphery. Chicago: University of Chicago dissertation.

Ouali, Hamid. 2006. On C-to-T $\phi$-transfer: The nature of agreement and anti-agreement in Berber. In Roberta D’Alessandro, Susann Fischer \& Gunnar Hrafn Hrafnbjargarson (eds.), Agreement restrictions. 159-180. Berlin: Mouton de Gruyter.

Pulleyblank, Edwin. 1995. Outline of Classical Chinese grammar. Vancouver: UBC Press.

Quer, Josep. 2009. Twists of mood: The distribution and interpretation of indicative and subjunctive. Lingua 119. 1779-1787. https://doi.org/10.1016/j.lingua.2008.12.003.

Wang, Li. 1980. Hanyu shigao [Essays on the history of the Chinese language]. Reprinted 2004. Beijing: Zhonghua Shuju.

Takahashi, Masahiko. 2012. On restructuring infinitives in Japanese: Adjunction, clausal architecture, and phases. Lingua 122. 1569-1595. https://doi.org/10.1016/j.lingua.2012.08.006.

van Urk, Coppe. 2015. A universal syntax for phrasal movement: A case study of Dinka Bor. Cambridge, MA: MIT dissertation.

Woolford, Ellen. 2006.Lexical case, inherent case, and argument structure. Linguistic Inquiry 37(1). 111-130.

Yang, Bojun and Leshi He. 1992. Gu Hanyu yufa ji qi fazhan [Archaic Chinese and its Development]. Beijing: Yuwen Publishers.

Yue, Anne O. 1998. Zhi in Pre-Qin Chinese. T'oung Pao 84. 239-292.

Zhang, Yujin. 2001. Jiaguwen yufaxue [Grammar of the Oracle Bone Inscriptions]. Shanghai: Xuelin.

Zhou, Fagao. 1959. Zhongguo gudai yufa [A Historical Grammar of Ancient Chinese] vol. 3. Taipei: Academia Sinica Institute of History and Philology. 